\title{
Protecting Child Labor in Bangladesh under Domestic Laws
}

\author{
Mahbub Bin Shahjahan', Mst. Jesmin Ara², Md. Ayaz ${ }^{1,3}$ \\ ${ }^{1}$ Department of Law \& Muslim Jurisprudence, Islamic University, Kushtia, Bangladesh \\ ${ }^{2}$ Department of Political Science, National University, Dhaka, Bangladesh \\ ${ }^{3}$ World Bank, Dhaka, Bangladesh \\ Email: shuvokkk@yahoo.com,jesmin_nu@yahoo.com, azadiub@gmail.com
}

Received 2 April 2016; accepted 17 April 2016; published 20 April 2016

Copyright (C) 2016 by authors and OALib.

This work is licensed under the Creative Commons Attribution International License (CC BY). http://creativecommons.org/licenses/by/4.0/

(c) (i) Open Access

\begin{abstract}
This study intends to raise awareness about the issues related to child labor in the formal and informal industry in Bangladesh. Child labor is now a global concern and as such involved devotion of people in various sectors. It tries to present the socio-economic scenario of child labor in Bangladesh which has in recent times attracted concerted attention not only in Bangladesh but also all over the world. Child labor problem is a socio-economic reality in the country which can't be ignored. Hereafter steps have to be taken at first to decrease child labor gradually rather removing it completely from the society. This study also focuses on the trend, impact and legislation of child labor in Bangladesh and this study is also an attempt to search out the ways by which child labor can be decreased gradually and at the end of the article these ways have been presented as recommendations.
\end{abstract}

\section{Keywords}

Child, Labor, Protection, Poverty, Domestic Law, Forced Labor, Industry

Subject Areas: Law

\section{Introduction}

Situated in South Asia, Bangladesh, bordering the Bay of Bengal between Myanmar and India, is the seventh most populous country in the world, with an estimated population of 151.4 million living in 147,570 square kilometers [BBS 2010] [1]. The country's economic conditions and social norms, child labor is widely accepted and common in Bangladesh. Many families rely on the income generated by their children for survival, so child labor is often highly valued. Additionally, employers often prefer to employ children because child labor is cheaper and children are considered more complaint and obedient than adults. Poverty emerges from unequal distribution of wealth and this virtually leads children to go to work and while discussing the causes of child la- 
bor, this article considers poverty as one of its principal reasons.

The country has a young population; the majority of child domestics tend to be 12 to 17 years old [BBS 2006] [2]. But children as young as 5 or 6 years old can also be found working and a survey of child domestic workers finds that 38 percent of the child workers 11 to 13 years old and nearly 24 percent of the child workers 5 to 10 years old [BBS 2002-03, SPBB 2003] [3]. The per capita gross domestic product (GDP) of Bangladesh was estimated at US \$684 in 2009-2010 [MoF 2010, BER 2010] [4], although the country's economy has grown at a rate of 5 - 6 percent per year since 1996 [CIA] [5]. Bangladesh remains a poor, overpopulated, and inefficiently governed nation. In fact, the Bangladesh Bureau of Statistics estimates that approximately 40 percent of the population lives below poverty line. Poverty is higher in urban areas (43.8\%) than in rural areas (28.4\%) [BBS 2006, HIES 2005] [6]. Following the observation, child domestics work long hours, getting up well before their employers and going to bed long after them and 50\% domestic workers work 12 - 14 hours a day [BBS 2010, SPBB 2009] [7].

The overhead statistics show a huge number of child workers who are working in the existing labor market and this clearly forces the society to pay attention to the child labor problem. Fairly discourse, when it is time to go to school with books in the hand, the ill-fated children of the country are being forced to work insensitively only for the existence and income generation of the family. In the working places, they are abused more than the adult workers. It is for these reasons that child labor has given some importance in Bangladesh.

\section{Objective of the Study}

The broad objective of the study is to gather on the movement, impression and regulation of child labor in Bangladesh and suggests some policy measures. The present manuscript aims to determine the present situation and the tendencies of child labor in Bangladesh, explore the reasons of child labor around the country, identify legislation governing child labor and measure affirmative and negative effects of it, understand what efforts of Government of Bangladesh is taking to address child labor, and make policy recommendations.

\section{Definition of Child Labor}

The child Marriage Restraint Act, 1929 imposes a gender distinction by setting the age of majority in order to contract a valid marriage at 21 years for men and 18 years for women. However, the children (Pledging of Labor) Act, 1933 and Employment of Children Act, 1938 determine that the minimum age for children as 15 and 12, respectively. To further complicate things, the Factories Act, 1965 states that individuals under 14 years of age are children whereas the Children Act, 1974 states that a child is an individual under 16 years of age. In addition, under contract law, a minor cannot enter into agreement until attaining the age of 18 . The 1989 United Convention on the rights of the child (CRC) and the 1999 International Labor Organization convention on the Worst Forms of Child Labor define a child as an individual under the age of 18 years, unless under the law application to the child majority is attained at an earlier age.

In response to these varying laws and the lack of a uniform age regime, the highly-anticipated 2006 Bangladesh Labor Act both consolidates and abrogates all of the existing labor laws and determines that a child is an individual under the age of 14. The Bangladesh Labor Act, 2006 defines an adolescent as an individual between the ages of 14 and 18. An adolescent can work in factory if a certificate of fitness is granted to him or her, if he or she carries a token while at work which gives reference to the certificate. An exception is provider for, as per section 44, a child who is 12 years of age may be employed if the work does not endanger his or her health or interfere with his or her education.

Child labor is defined as work that deprives children of their childhood, their potential and dignity and is harmful to physical and mental development. UNICEF, the United Nations Children's Fund, defines child labor as work that exceeds a minimum numbers of hours, depending on the age of a child and on the type of work. For children aged 5 to 11, this would include at least one hour of economic work or 28 hours of domestic work per week. For the 12 to 14 age group, this would include at least 14 hours of economic work or 28 hours of domestic work per week and for children aged 15 - 17, child labor occurs when a child works at least 43 hours of economic or domestic work per week.

\section{Child Labor and Forced Child Labor in Bangladesh}

ILO Convention 182 (Article 2) defines children as all persons under age of 18. In the absence of formal evi- 
dence that children under 5 years old are engaged in work, official statistics do not include children in that age group. National statistics, therefore, treat those aged between 5 and 17 years old as the universe from which child labor is drawn [UNICEF, 2010] [8].

The report on the National Child Labor Survey (NCLS) 2002-2003 showed that of the 42.4 milion Bangladeshi children between 5 and 17 years old, 7.4 million were economically active [NCLS 2002-2003] [9]. Since independence, Bangladesh has been incrementally engaged in raising awareness and initiating protective measures against the use of child labor. Even so, over the years, the absolute number of child workers has increased significantly because of a combination of factors, an increase in population, a persistently impoverishing situation in rural areas; and migration from rural to urban areas because of poverty, erosion of land by rivers, inheritance laws, and the breakup of families. The number of economically active children rose from 4.1 million in 1989 to 6.3 million in 1996, and 7.4 million in 2003 [9].

However, the Bangladesh Annual Labor Survey (BALFS) 2005-2006, which is designed to cover the whole labor force-not just children-estimated that a total of 5.1 million children 5 - 17 years old were economically active [BALS 2005-2006]. [10] The previous NCLS covering the period 2002-2003 permits a look at how the level and composition of children's activities, particularly children's reemployment, changed from 2002-2003 to 2005-2006. A comparison of the results from the two surveys shows a decline in children's employment of 5 percentage points during this period (from $17 \%$ to $12 \%$ ). The apparent progress in reducing the number of economically active children during this period extended to both boys and girls, and to both urban and rural places of residence [ILO, UNICEF, WB 2001, UCWB 2001] [11].

It is also estimated that there were approximately 420,000 child domestic laborers 5 - 17 years of age in Bangladesh in 2005, of which approximately 147,000 (35\%) were in Dhaka city alone, meaning that they completely depend on their employers and often have restrictions on their mobility and freedom. Approximately 60 percent of these working children report some kind of abuse during their work, such as scolding or slapping. Levels of exploitation are also extremely high, as indicated by the fact that more than half receive no wages at all. The numbers involved make child domestic laborers the single largest hazardous child sector in the country [ILO, 2006] [12].

Since those statistics were produced, NCLSs conducted by the Bangladesh Bureau of Statistics (BBS) on the worst forms of child labor in five segments (automobiles, battery recharging, street children, transport, and welding) have summarized the situation as follows [Ali 2009] [13].

Extreme forms of poverty play a crucial role in increasing child in Bangladesh. Child labor is part of a vicious cycle, with poverty as its main cause as well its main consequence. This implies that child laborer cannot be addressed in isolation.

Among the factors contributing to child labor are rapid population growth, adult unemployment, income erosion due to the negative health consequences of bad working conditions, lack of minimum wages, exploitation of workers (i.e., mostly low wages, standard of living, quality of education, and capacity of institution; lack of legal provisions and enforcement gender discrimination, conceptual thinking about childhood). One or more of the above conditions contribute to the large number of children working under exploitative or hazardous conditions.

There is a direct link between child labor and education. Among the 42.4 million of children ages 5 - 7 years, approximately 5 million (11.80\% were working and not attending school. Furthermore, nearly 59 percent of primary school students drop out before they complete grade 5; they then gravitate towards work, thus swelling the number of child laborers.

However, the level of awareness on the issue of child labor is still now. Society has a rather indifferent attitude toward the problem. In many cases, it is not realized that the children who are employed in domestic service, for example, often have no access to education or medical care [Ali 2009] [13].

\section{Child Labor in Various Sectors}

Child labor in Bangladesh is not a new issue as children remain here as one of the most vulnerable, exploited, underprivileged, dominated and subservient groups. Indeed, child labor in Bangladesh is alarming in various sectors which can be observed in a survey of 2002-2003 conducted by the Bangladesh Bureau of statistics. At, present, in Bangladesh 7.9 million children ages 5 - 17 work, children represent $16.6 \%$ of the total workface, $62 \%$ of all working children are employed in agriculture, 149,000 children are engaged in the worst forms of child labor and 1.4 million children do hazardous work [14]. Besides, the highest proportion of working children, 
some 49.5 percent, was found involved with informal sector that means, unpaid economic activities in family farms or business. It was also found that $28.6 \%$ were employed as paid day laborers, $14 \%$ were sales workers while transport sector engaged 25.4\% of them [BBS 2002-2003] [15] (Table 1).

There is a clear-cut distinction between urban and rural working sectors. Rural working children are mainly engaged in agricultural activities and urban working children are mostly involved with formal working sector. The aforesaid survey found similar trend. According to the survey, 2.5 million urban working children are laboring in the formal working sector where they are always faced with dismal, deplorable and abject working conditions, unfixed wages, health hazards, lack of recreation and are exposed to mental, physical and sexual harassment. It is also mentionable that usually children working in the industrial sector have no contract of employment and his ultimately makes it difficult for them to stand up and fight for their rights. Practically, working children are used and exploited for the benefit of the better off sector of society. This is not really deliberate exploitation of children by the wealthy rather reflects the attitude of the society. That means, employers prefer children as they are cheap, productive and obedient [16].

The child laborers are also engaged in some of the hazardous jobs where the rate of child labor is high, working atmosphere unhygienic, ages abnormally low and wages unfixed. Apart from these, a large number of children predominantly girls, whether in the urban and rural areas, are employed as domestic helps. In total contrast, boys in the villages look after the domestic animals and in the cities are engaged in marketing, taking children of the householder from school etc. Such works are not hazardous and may be good if they are provided adequate food, clothing, and place to sleep and treated politely and mercifully when they commit wrong [17].

\section{Child Labor in Bangladesh Garments Industry}

For Bangladesh, garment export, totaling $\$ 12.3$ billion in fiscal year 2009, account for 12 percent of the country's GDP and are the most important export product [BBS 2008-2009] [18]. Bangladesh's formal garment industry is reportedly free of child labor. Given the significance of the industry, the garment sector was once a significant employer of child workers-mostly girls-in Bangladesh, until the introduction of the Harkin Bill in the U.S. Senate in 1992; the bill aimed to prohibit importation into the United States of manufactured and mined goods that are produced by children under the age of 15 [ILO-IPEC 2004] [19].

Although the Harkin Bill was never passed, the BGMEA responded by urging its members to remove underage workers from their workplace, in conformity with Bangladesh's factory Act, which sets a minimum age of 14 years for employment [ILO-IPEC 2004] [19]. An estimated 10,000 - 30,000 children-mostly girls-were said to be employed in the garment manufacturing industry prior to BGMEA's response in 1993 [Feldman \& Larson 2004] [20]. Citing a BBS survey, Global March against Child Labor states that this has contributed to the decline of child labor in Bangladesh by as much as 22 percent since 1995-1996, more notable for girls (43\%) than for boys (6\%) [BBS 1995-1996-2009] [21].

Table 1. Child labor in various sectors in Bangladesh.

\begin{tabular}{|c|c|}
\hline Automobile & Repair, servicing, cleaning, spraying, polishing, vulcanizing \\
\hline Engineering & Metal cutting, shaping, molding, tool and die manufacture, nut/screw/bolt manufacture, welding \\
\hline Electrical & All types of electric work, refrigeration and AC repair and recharge \\
\hline Metal work & Tin work, aluminum recycling, casting, painting, hurricane lamp fabrication, steel furniture manufacture \\
\hline Plastic & Plastic recycling, molding, shaping, production of sandals, balloon production, etc. \\
\hline Woodwork & Carpentry, furniture manufacture, shaping, polishing \\
\hline Textile & Tailoring, embroidery, dyeing, weaving, mattress fabrication \\
\hline Food & Cooking and food preparation, biscuit and bread baking, flour and spice milling, salt manufacture \\
\hline Skill trades & Plumbing, goldsmith, blacksmith, book binding, printing \\
\hline Transport & Tempo/bus, ferry helper, porter \\
\hline Leather & Cleaning, cutting, shaping, sewing, shoe manufacture \\
\hline Chemical & Battery breaking, soap manufacture, packing and weighing \\
\hline Scavenging & Collecting waste plastic, paper, glasses, jars, toys, rubber items, steel items, food items, tin items, animal bones, etc. \\
\hline Glass & Recycling, cleaning, smashing, melting, molding, bangle production \\
\hline
\end{tabular}

(Source: Breaking the Cycle, Key Learning from an ILO-IPEC Project in Bangladesh, 2008) 
Bangladeshi garment workers reportedly work in hazardous environments and under exploitive conditions [HRL 2008] [22]. For instance, cases have been reported where the exit doors of the factories/workplaces have been locked, which has often resulted in high casualty counts when accidents happen [23]. Although wages were sometimes higher than the minimum required wages because of skilled labor shortages, it has been reported that garment factories sometimes force workers to work overtime, delay their pay, and deny them full-leave benefits. These working conditions led to tension between garment workers and employers, which in turn led to clashes and violent demonstration periodically [24].

\section{Causes of Child Labor}

Causes of child labor can be discussed from different aspects and it is agreed and seen that the problem of child labor is substantially located in the developing countries. Accordingly in Bangladesh also child labor is very high and its causes are varied some of which are as follows.

\subsection{Poverty}

The main cause behind child labor is poverty. The National Labor Elimination Policy, 2010 also identified it as the first and chief reason behind children involved in working. In Bangladesh, around 55 million people are considered to live below in poverty line. They have no surety to food and this compels many of the parents to send their children to work. Truly, for many forcing their children to work is the only way to survive.

In Bangladesh, 67\% children work due to financial hardship, either to contribute labor for wages to supplement household incomes or to work at home so that adults can work outside [25].

\subsection{Lack of Awareness and Embedded Tradition}

Lack of awareness and the firmly established tradition also play an important role to prolong child labor. Indeed, most of the parents are unaware about the notion of "Child labor". They know neither what is meant by child labor nor the harmful effects of it. Again because of the embedded tradition in our society majority of the parents think that their children will earn from early ages and will contribute to the family budget, though there may be no compelling necessity.

\subsection{Lack of Education of Parents, Especially in Mothers}

Lack of education the parents neither understand what child labor is nor what are its effects, as such they very often encourage children and in some cases put pressure on them to work instead of going to school, though they are not in need of work. A UNICEF survey of selected countries in Latin America, the Caribbean, South Asia and Sub-Saharan Africa finds that on average children with uneducated mothers are at least twice more likely to be out of primary school than children whose mothers attended primary school (UNICEF, 2010).

\subsection{Parents Feeling of Insecurity about Their Children}

Many parents in our society fear that if their children spend their time idly, they may get involved in anti-social activities. For this reason they try to find an occupation for their children and keep them away from idleness and vagrancy.

\subsection{Miscellaneous Factors}

Besides the above reasons, many children engage in work in order to supplement the family income and the parents do not even restrict them. They see nothing abnormal in working at an early age. Further, due to the internal migration that takes place from one place to another within the country, many parents fall into hard financial crisis which also lead children to go to work for survival. Inadequate recreational infrastructure also engages many children in work. Furthermore, insufficiency of schools, poor curriculum, absence of proper nursing and care of pupils by the teachers, lack of usefulness of education for their survival and profession and the long time needed for education also lead some children to begin work at an early age. Another point is that many people in our country employ children violating the labor laws, but there is no punishment for such violation. Government has so many laws but implementation is missing. Though this is not a cause of child labor, but this non-implementation 
is encouraging the employers to use child labor in making their products or in performing their businesses. At the end it can be said that though poverty is the principal cause behind child labor, child labor is also caused by a variety of others reasons.

\section{The Laws and Policies in Bangladesh Regarding Child Labor}

As one of the countries with high prevalence of child labor, ever since its independence Bangladesh has remained politically committed to, and incrementally engaged with, rigorous policies and programs/projects to reduce child labor and lead to its eventual elimination. Bangladesh has already passed the milestones of ratifying the United Nations Convention on the Rights of the Child and Convention 182 on prohibiting worst forms of child labor, and is moving towards ratification of ILO-IPEC Convention 138 against the backdrop of the adoption of National Child Labor Elimination Policy of 2010 [TBP-ILO 2006] [26]. This policy provides a framework for eradicating the worst forms of child labor. The policy serves as a guiding instrument for the formulation of future laws and policies regarding child labor. The policy also calls for the formation of a National Child Labor Welfare Council to monitor the child labor situation at the national level [USDOL 2010] [27].

Although not specifically concerned with child labor issues, the Birth and Death Registration Act of 2004 addressed one of the fundamental human rights specified in the convention on the Rights of the child-that all children have the right to a name, identity, and nationality. Birth registration is a first and significant step in upholding these rights. Birth registration is state's first official acknowledgement of the child's existence; it is also the means to secure other child rights such as access to health care and education. In addition, birth registration protects children from exploitation because it enables the use of legal age limits for employment, marriage, recruitment for armed forces, and criminal responsibility [28].

The Government of Bangladesh committed itself to achieving universal birth registration by 2010, with registration numbers having significantly increased since initial targets were set in 2008 [29]. Final completion was delayed until December 2011 [30].

Bangladesh enacted the Labor Act in 2006, which includes a chapter on child labor. This new law prohibits employment of children under 14 years old, as well as hazardous forms of child labor for persons under 18. However, children who are ages 12 and older may be engaged in "light work" that does not pose a risk to their mental and physical development and does not interfere with their education. The law does not provide a strong enforcement mechanism for its child labor provisions. Additionally, the vast majority of children (93\%) work in the informal sector. This makes it challenging to enforce the relevant legislation.

The recent adoption of National Child Labor Policy 2010 and the third National Plan of Action (NPA) for Children (20005-2010) also stands as testimonies of Bangladesh's commitment to the issues of child labor and child rights. The recently finalized National Child Labor Elimination Policy of 2010 aims to eliminate children from every sort of hazardous and worst forms of child labor category task, and to bring meaningful change to the lives of many Bangladeshi children. The specific objectives of the policy are as follows:

- Withdraw working children certain forms of occupation;

- Involve parents of working children in income-generating activities;

- Offer stipends and grants to children and families in order to bring working children back to school;

- Extend special attention to children who are affected by natural disasters;

- Provide special emphasis to indigenous and physically challenged children to bring them back to a congenial environment;

- Ensure coordination among the concerned stakeholders who work for the welfare of working children;

- Enact pragmatic laws and strengthen institutional capacity for their enforcement;

- Raise awareness among parents, the people, and civil society about the harmful consequences of child labor;

- Plan and implement different short, medium, and long-term strategies and programs to eliminate various forms of child labor from Bangladesh by 2015 [MoLE 2010, NCLP 2010] [31].

Based on the National Child Labor Elimination Policy 2010, a National Plan of Action has been finalized to implement the policy with support from ILO-IPEC, UNICEF, save the children and other child labor-related stakeholders. It is expected that the Ministry of Labor and Employment (MoLE) will very soon officially declare the plan for implementation, although no such declaration had been made. Some observers consider the plan's target of eliminating child labor by 2016 to be unrealistic [32]. In the meantime, the MoLE has also finalized the list of hazardous work, which has been technically cleared by the MoLE; through high power Tripartite Technical Consultative Group [31]. 


\section{Programs in Bangladesh Regarding Child Labor}

ILO-IPEC was launched in 1992 to progressively eliminate child labor through strengthening national capacities to address child labor problems. The TBP is one of the means established by ILO-IPEC to help countries fulfill their obligations under ILO convention 182 to take immediate and effective time-bound measures' to prohibit and eliminate the worst forms of child labor as a matter of urgency.

The Urban Informal Economy (UIE) project is one of the projects supported by ILO-IPEC as part of the TBP in the Dhaka and other metropolitan areas of Bangladesh. The project succeeded an ILO-IPEC pilot project that began in 2001. The pilot project focused on building a knowledge base on the sectors and actors in the urban informal economy and on testing strategies and models for validity and cost-effectiveness [33].

UNICEF is advocating for a national child protection system to support all vulnerable children, including working children and the victims of trafficking, violence, abuse and exploitation. The system will link all organizations and institution (public and private) that support children at risk. Outreach activities will identify different groups of vulnerable children and help them access services for health, shelter, education, social and legal assistance. To support the network, UNICEF is facilitating the development of a national child protection information management system and the design of national social services training [34].

Among many of its activities in Bangladesh, Save the Children has been working with the Government of Bangladesh and NGOs in five districts to set special schools that are open during break times and at night. Here, working children can drop in and catch up on missed classes. Save the children says that 2500 children between the ages of 5 and 12 are benefiting from this initiative and that approximately 2600 children are able to obtain free basic medical advice and treatment through a referral system to NGO-run clinics and government health centers [35].

In 2011, CARE Bangladesh launched the Providing Working Children with Functional Education and Marketable Skills project. Set to run until April 2014, the project will, according to the job description, seek to implement life skill education as the guiding values for working children [36].

The Manusher Jonno Foundation runs a Child Protection and Development (CP\&D) program. Through its partners, it targets children in who are in hazardous work and in vulnerable and disadvantaged situations. The program builds capacity to address child rights violations; improves and facilitate processes so that vulnerable children may access basis services such as education, health and recreation, thereby realizing their capabilities; and addresses key sensitive issues, such as sexual abuse and other forms of violence against children. The foundation notes that the program provides protection and development for 131,622 children directly and altogether addresses the needs of 658,110 people [37].

The Resources Integration Center (RIC) initiated the second phase of its Basic Education for Hard-To-Reach Urban Working Children program in 2004, in collaboration with the Government of Bangladesh, UNICEF, and SIDA (Sweden). The long-term objective was to enhance the life options of urban working children and adolescents by helping them access their rights to education, protection, development and precipitation. Specifically the program sought to provide high-quality non-formal, basic education rooted in life skills to 200,000 urban working children and adolescents 10 - 14 years old, and to provide 20,000 urban working children and adolescents with livelihood skills training, as well as access to support systems in order to ensure optimal use of life skills [38].

\section{Recommendation for Protecting Child Labor in Bangladesh}

Child labor is a challenging and worthy task and requires financial, moral and political support from all the levels of the society. In reality, child labor can't be virtually removed from a country such as Bangladesh just now because the problem of child labor is indissolubly rooted in our society, so attempts have to be made in the first place to decrease it.

Poverty is the core reason behind child labor as it drives children to involve in employment in order to fight against starvation as well as to supplement the family income, so effective solutions to child labor must be based on the reduction of chronic poverty through broad based economic and social development, with a strong emphasis on human resource development. As such, my contention is that with a view to elimination or decreasing child labor, along with poverty eradication, child centered educative sensitivity and awareness at political, community and family level is essential.

Take the case of child-centered educative sensitivity at first. To create such kind of sensitivity educated par- 
ents, educated family members and an educated community has to be made and they will actually play an important role in the progressive elimination of child labor. In this regard existing schooling process should be borne in mind. Schooling process has to be changed and an upgraded curriculum to be introduced inclusive of basic idea regarding child labor. Besides that, to make education effective, arrangement should be made in the expected modified curriculum around vocational training that would enable students to achieve an employment quickly and easily after finishing their schooling period.

Then take the case of awareness raising. Education makes a person more conscious than in any other ways. Inclusion of knowledge about child labor in school curriculum may also be used as a method of awareness building. At the same time government and other non-government organizations may make people aware through distributing leaflet among the common mass; showing advertisement, movie and short films on the television.

Income generation and employment creation for adults help to reduce poverty which leads to, besides poverty elimination, child-centered educative sensitivity and awareness raising, effective solution of child labor problem.

In rural areas employment opportunities in various sectors has to be created so that the villagers are not inclined to go to urban areas for seeking employment which virtually in many cases land them into insecurity, instability and poverty and actual this urbanization and migration lead migrated people to send their children to work in order to free themselves from the unavoidable circumstances of the urban life.

Some issues as regards child legislation are necessary to be pointed out. Policy and legal instruments dealing with other issues such gendar-based violence and child labor are often narrow in focus and do not address the best interests of children experiencing violence. Laws against child labor are applicable only to the formal economic sectors. But most children who work in the informal sector, such as small factories, workshops, motor garage, shops, agriculture or domestic work, are not regulated by law nor are these establishments monitored by any government agency. Again, legislation concerning child labor is proper from the context of prohibiting it but is improper for not implementing the concerned laws. For this reason enforcement procedures has to be strengthened and law enforcement agencies have to be free from any influence. The old archaic laws have to be excluded and according to the changing social-economic circumstances new laws covering the informal sectors not embraced in the Act at the present time have to be passed. In case of changing the domestic laws government may follow the standards set by the international forum. Based on its constitutional obligation and its commitment to international standards on children (CRC and the Worst Forms of Child Labor ILO Convention No. 182), it is obvious that the government will need to take the lead in pursuing child labor elimination goals, in order to meets it long-term development needs. The most important recommendations are therefore those that relate to the adoption of the establishment of an inter-ministerial National Taskforce on Child Labor and Education, a review and effective implementation of the Labor Act (2006) and the urgent need to increase the capacity of the recently established Child Labor Unit and to ensure that the unit can bear its responsibilities and function effectively.

\section{Conclusions}

Children are the future optimism of a state. Therefore, if they are exploited at a very early age, they would not be able to contribute to the country and would hamper progress. Moreover, children consistently express their concerns about the absence of safe environment, which leads to violence, abuse and exploited within the family, community, street, work place and school, in state and non-state institutions and also in the justice system. The current governance deficit in Bangladesh has further aggravated the situation because the duty bearers such as lawmakers, executives, police, probation officers and even judges remain insensitive to children's rights and fail to provide protection, special care and treatment. It is necessary to mention here that the government is committed to protect the child but it lacks depth of understanding and consistent planning. That's why action at the national level is needed now, as timely taken steps can only bring positive impact on decreasing or elimination of child labor from all tiers of the society. But in case of taking action in full conformity with reality, all the factors such as, economic, social, political, cultural have to be taken into consideration. Moreover, child sensitivity approach has to be strong along with adopting multiplier measures. But the good news is that child labor problem has attracted a large concerted attention in recent times and the government, NGOs and some private organization are though less then needed, working with a view to solving the problem and consequently the rate of child labor has decreased in little. Further, Bangladesh is a signatory to, and has ratified, most of the major interna- 
tional conventions related to children, except for the ILO Minimum Age Convention (No. 138). Again, it has introduced a number of policies and plans over the years intended to reduce or eliminate child labor.

Bangladesh is obliged under both national and international law to protect and promote the rights and interests of children. The constitution of Bangladesh and the Children's Act, 1974 guarantees basic and fundamental human rights and ensures affirmative action for children. These rights are the guiding principles for formulating policies and laws relating to child development. In conclusion, we earnestly hope that as Bangladesh is one of the earliest signatories of the Convention on the Rights of the Child (CRC), therefore these initiatives will be widespread and the affluent, elite countries and international organizations will come forward to help our government and NGOs not only in case of financial assistance but also in the actual performance of the field-level work.

\section{References}

[1] Bangladesh Bureau of Statistics (2010) Statistical Pocket Book of Bangladesh 2009.

[2] Bangladesh Bureau of Statistics (2006) Household Income Expenditure Survey 2005.

[3] Bangladesh Bureau of Statistics (2002-2003) Statistical Pocket Book of Bangladesh 2003.

[4] Ministry of Finance (2010) Bangladesh Economic Review 2010.

[5] CIA World Fact Book, Bangladesh. Available at https://www.cia.gov/liabray/publication/the-world-factbook/geos/bg.html

[6] Bangladesh Bureau of Statistics (2006) Report on Household Income Expenditure Survey 2005.

[7] Bangladesh Bureau of Statistics (2010) Statistical Pocket Book of Bangladesh 2009.

[8] UNICEF (2010) Child Labor in Bangladesh. Available at https://www.unicef.org/bangladesh/childlabor.pdf

[9] As Defined in NCLS 2002-2003, Economically Active Children Refer to the Children under Age 18 Who Have Worked for 1 or More Hours, with or without Pay, in Any Form of Occupation during the Last 7 Days.

[10] Bangladesh Annual Labor Survey 2005-2006.

[11] International Labor Organization, UNICEF, The World Bank (2001) Understanding the Children’s Work in Bangladesh. Country Report, July 2011.

[12] ILO (2006) Baseline Survey for Determining Hazardous Child Labor Sectors in Bangladesh 2005.

[13] Masud Ali, A.K.M. (2009) Mapping of Policies and Legislation and Analysis of Child Labor Programs in Bangladesh, UNICEF.

[14] Last visited on 26.01.2016. www.concernusa.org

[15] Bangladesh Bureau of Statistics (2002-2003) Statistical Pocket Book of Bangladesh 2003.

[16] The Daily Star, 11 November 2006, Page 1, Col 6.

[17] The New Nation, 25 November 2004, Page 5, Col 3.

[18] Bangladesh Bureau of Statistics (2008-2009) Statistical Pocket Book of Bangladesh 2009.

[19] ILO-IPEC (2004) Addressing Child Labor in the Bangladesh Garment Industry: 1995 to 2001. Available at https://www.org/ipecinfo/product/download:do?type=document\&id=556

[20] Feldman, S. and Larson, D. (2004) Child Labor in Global View. Greenwood Press, Westport.

[21] Bangladesh Bureau of Statistics (1995-1996-2009).

[22] U.S. Department of State, Bureau of Democracy, Human Rights and Labor (2008). Available at http://www.state.gov/g/drl/rls/hrrpt/2007/100612.htm

[23] Available at http://libcom.org/news/article.php/bangladesh-garment-revott-140706

[24] The Daily Star (2010). Available at http://www.thedailystar.net/newDesign/latestnews.php?nid=27381

[25] The New Nation, Online Edition (2004).

[26] National TBP Framework, Project Document, TBP-ILO (2006).

[27] USDOL (2010) 2009 Findings on Worst Forms of Child Labor. Accessed on 20 January 2016. Available at http://www.dol.gov/ilab/programs/ocft/pdf/2009

[28] Accessed on 20 January 2016. Available at http://www.unicef.org/bangladesh/BirthRegistration(1):pdf

[29] Accessed on 20 January 2016. Available at http://www.idlo.int/doccalender/bangladeshreport

[30] Accessed on 20 January 2016. Available at http://www.lgd.gov.bd/index.php?option=com 
[31] Ministry of Labor and Employment (2010) National Child Labor Policy 2010.

[32] Available at http://www.thefinacialexpress-bd.com/more.php?newsid=98169\&date=2011-12-21

[33] Accessed on 20 January 2016. Available at http://www.ilo.org/dhaka/whatwedo/projects/wcms

[34] Accessed on 11 January 2016. Available at http://www.unicef.org/bangladesh/4926-4959.htm

[35] Accessed on 20 January 2016. Available at http://www.savethechildren.org.uk/where-we-work/asia/bangladesh

[36] Accessed on 11 January, 2016. Available at http://www.hotjobs.bdjobs-server.com/bdjobs/care/care35.htm

[37] Accessed on 10 January 2016. Available at http://www.manuser.org/how.php

[38] Accessed on 8 January 2016. Available at http://www.ricbd.org/edu.php 